WSRC-TR-95-0183

Publication Date: April 1995

\title{
Soil Washing Technology Evaluation ${ }^{(\mathrm{U})}$
}

Ahmet Suer

Environmental Restoration Engineering

(803) $644-6900$

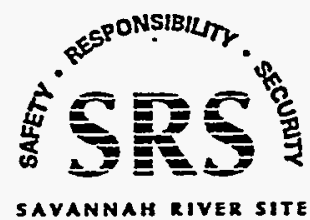

Prepared for the U.S. Department of Energy under Contract No. DE-AC09-89SR18035

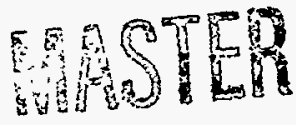


This page intentionally left blank. 


\section{DISCLAIMER}

This report was prepared as an account of work sponsored by an agency of the United States Government. Neither the United States Government nor any agency thereof, nor any of their employees, make any warranty, express or implied, or assumes any legal liability or responsibility for the accuracy, completeness, or usefulness of any information, apparatus, product, or process disclosed, or represents that its use would not infringe privately owned rights. Reference herein to any specific commercial product, process, or service by trade name, trademark, manufacturer, or otherwise does not necessarily constitute or imply its endorsement, recommendation, or favoring by the United States Government or any agency thereof. The views and opinions of authors expressed herein do not necessarily state or reflect those of the United States Government or any agency thereof. 


\section{DISCLAIMER}

Portions of this document may be illegible in electronic image products. Images are produced from the best available original document. 


\section{Contents}

Introduction

Technology History .................................................................... 3

Technology Description................................................................ 5

Potential Application ....................................................................9

Technology Advantages .............................................................. 11

Demonstration and Remediation

Projects Overview ............................................................... 13

WSRC Soil Remediation Task Team ............................. 15

Treatability Study Guidance .................................................... 17

Soil Washing Cost..................................................................... 21

Conclusions .................................................................................. 23

Bibliography .................................................................................. 25

Appendix A-Superfund Sites Using Soil

Washing as Selected Remedy ......................................... 27

Appendix B-Overview of Soil Washing

Technology Applications in the U.S................................. 31

Appendix C-Soil Washing

Contractor/Vendor List 55

List of Figures

1. Conceptual Soil Washing Process ........................................ 6 



\section{Introduction}

Environmental Restoration Engineering (ERE) continues to review innovative, efficient, and cost effective technologies for SRS soil and/or groundwater remediation. As part of this effort, this technical evaluation provides review and the latest information on the technology for SRS soil remediation. Additional technology evaluation reports will be issued periodically to update these reports.

The purpose of this report is to review the soil washing technology and its potential application to SRS soil remediation.

To assess whether the Soil Washing technology is a viable option for SRS soil remediation, it is necessary to review the technology/process, technology advantages/limitations, performance, applications, and cost analysis. 



\section{Technology History}

Soil washing was developed in early 1980 in Holland and was used in Europe extensively. The technology was transferred to the United States. In early development, the soil washing technology developers used existing mining and chemical processes to remove contaminants.

In October 1990 EPA Technology Innovative Office (TIO) was tasked to foster the use of soil washing and other innovative technologies for SRS soil remediation. Despite TIO's efforts, soil washing has limited use in the United States despite its success at Superfund sites throughout the United States. In addition, TIO provides technical assistance to EPA Remedial Project Managers (RPM) and On-Scene Coordinators (OSC) to promote the tech-. nology.

As of January 1995, EPA issued 1364 Records of Decision (RODs), and soil washing was selected as the preferred remedy at 24 RODs. A list of Superfund sites using soil washing as the selected remedy are presented in Appendix A. 


\section{- This page intentionally left blank.}




\section{Technology Description}

Soil washing is an innovative technology that uses physical and/or chemical separation processes. It is ex situ technology used to process excavated soil. Contaminants are removed by chemical and/or mechanical processes that concentrate them into a smaller volume. The soil washing technology is also known as Volume Reduction Unit (VRU).

Hazardous compounds tend to bind, chemically or physically, to silt or clay. Silt and clay are attached to sand or gravel by a physical process, e.g., adhesion. Soil washing separates fine and clay fractures from sand and gravel, and concentrates contaminiants into the fine fractures. By further treatment methods, clay and silt particles are treated or disposed of according to applicable regulations.

Soil washing generally consists of several unit processes, which I call "black boxes" that separate soil components from contaminants. Soil washing is "flexible unit", based on contaminants and concentrations present. Additional treatment systems can be attached as (pre) or-(post)-treatments.'This will minimize or eliminate secondary_waste. Soil_washing units are modular and mobile.

Soil washing technology performance depends on:

- Soil physical characteristics

- Soil chemical characteristics

- Hazardous compound physical and/or chemical properties

Figure 1 shows a conceptual soil washing process. Soil Washing consists of the following processes:

- Screening

- Particle size separation

- Coarse fraction treatment

- Fine fraction treatment

- Sludge treatment

- Secondary waste management

A brief description of the process follows:

Screening-The objective of the screening process is to separate oversized fractions, debris, metals, and rocks. These large fractions are generally not contaminated, and are therefore separated. Also, blending of fractions will provide consistent quality of waste for treatment. Excavated soil is piled at the site and processed through the screening. Various types of screening tools and methods are: vibrating grizzly screens, specific gravity separation (jigging), grinding, screening, and magnetic separation.

Particle size separation-Vendors claim that this is the heart of the technology. It is used for concentrating contaminants in preparation for treatment. Cyclones, which are approximately 36 inches high and 16 inches in diameter are commonly used for separation. Coarsegrained material is spun out of the bottom, while fine-grained material and water are ejected 


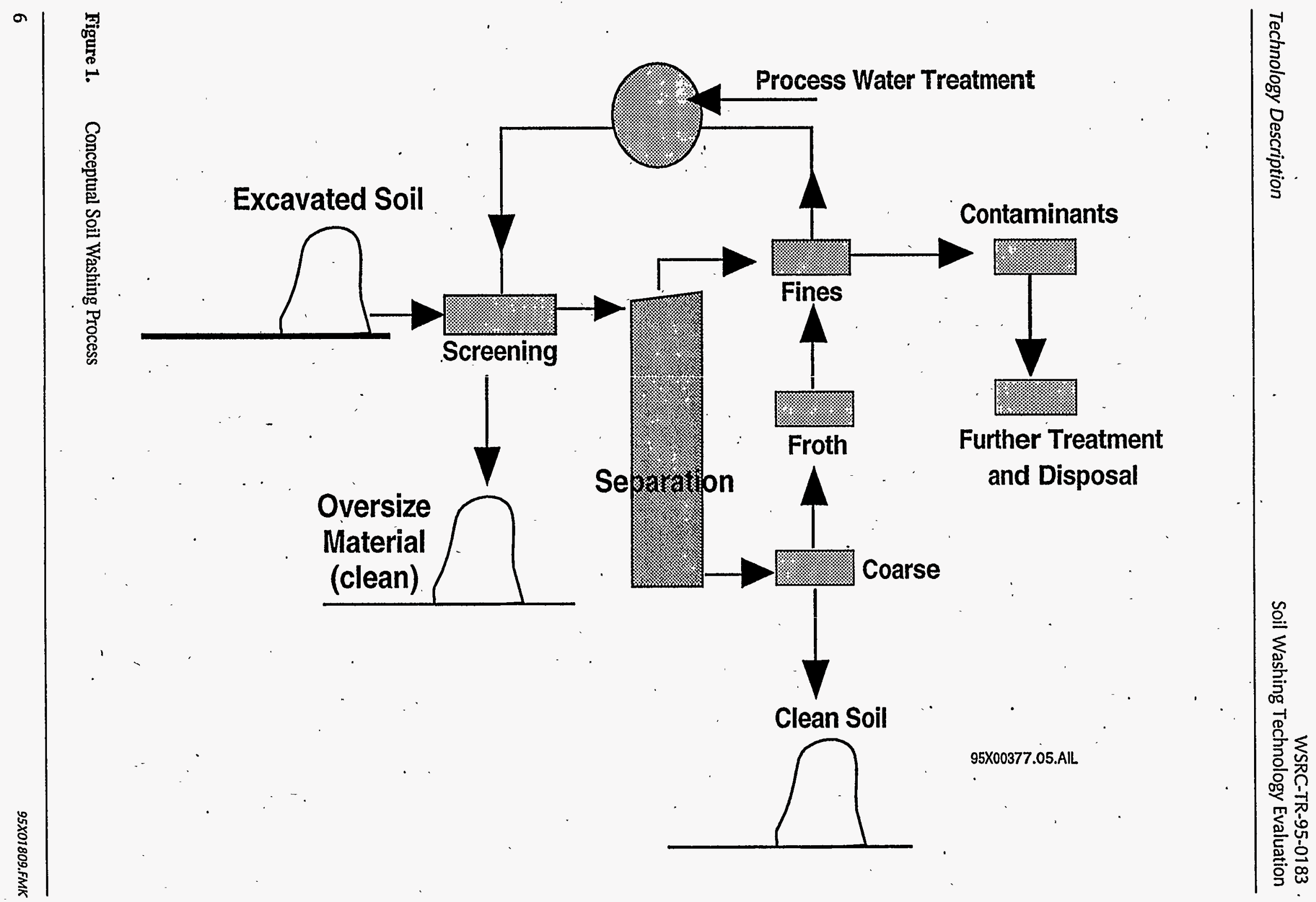


from the top. Depending upon soil particle size distribution, the cyclone design is a very critical part of the soil washing process.

Other size separation processes are: physical size fraction, gravimetric separation, chemical separation and upflow classifiers (hydrosizer).

Coarse fraction treatment-Contaminants tend to bind to the finer fractions of the soil; however, a small percentage of contaminants bind to coarse particles. Debris washing, attrition scrubbing, or flototation methods may be effective in removing the contaminants.

Fine fraction treatment-These fractions are less than 200 mesh (63 microns). Overflow coming from the separation process will be very diluted, and settle very. slowly. However, clay fractions (sizes less then 63 microns) may not settle. These fine fractions may be removed by flocculation, with the aid of chemical flocculent. If contaminants are metals or pesticides, chemical chelating agents may be used.

Process water treatment-The soil-washing process water used in soil washing with pressure and/or high temperatures, are treated with conventional wastewater treatment technologies and recycled in to the system.

Secondary waste management-Secondary waste generation depends on:

- Soil particle size distribution

- Soil washing processes

- Contaminants

Contaminated fine fracture may be disposed of in a landfill, or sent for further treatment such as; biological, vitrification, incineration, and solidification/stabilization. 
This page intentionally left blank. 


\section{Potential Application}

Soil washing technology can be used as stand-alone technology or in combination with other technologies to reduce secondary waste.

Effectiveness of soil washing for a wide range of contaminants is shown below.*

Contaminant

Organics

Halogenated volatiles

Halogenated semivolatiles

Nonhalogenated volatiles

Nonhalogenated semivolatiles

PCBs

Pesticides

Dioxin furan

Organic cyanide

Organic corrosives

Inorganics

Volatile metals

Nonvolatile metals

Radioactive materials

Inorganic corrosives

Cyanide

Asbestos

Reactive

Oxidizers

Reducers
Sandy/Gravel Soils .

Silt/Clay Soils

Y

$\mathbf{M}$

$Y$

$\mathrm{Y}$

M

M

M

M

M

\section{Y}

$Y$

M

M

M

NA

M

M
M

M

M.

M

M

M

$\mathrm{M}$

M

M

M

M

M

$\mathrm{M}$

$\mathrm{M}$

NA

Y Good to excellent applicability

M Moderate to marginal applicability

NA Not applicable

* Source: U.S.EPA Soil Washing Engineering Bulletin, September 1990 
This page intentionally left blank. 


\section{Technology Advantages}

The major advantages of soil washing technology are:

- Applicable to metals, radionuclides, and organics

- Great volume reduction achieved

- Treat only contaminated fraction

- Onsite and mobile system

- Cost effective

- Requires minimum permits 


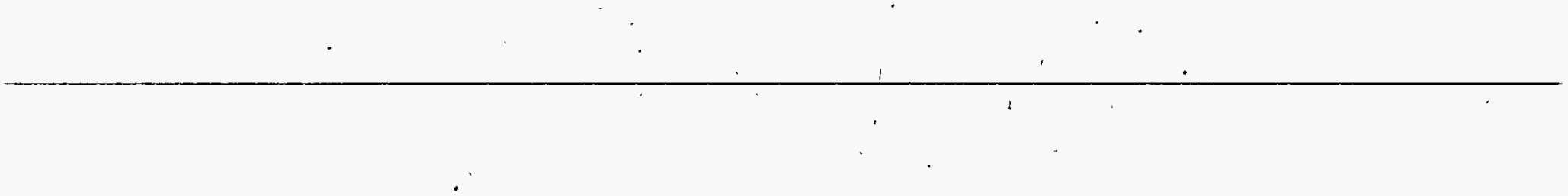




\section{Demonstration and Remediation Projects Overview}

As of January 1995 soil washing technology was selected at.twenty-four Superfund sites throughout the United States. Appendix A presents information on these twenty-four sites, e.g., site name, city, state, EPA region number, and the ROD dates.

The project status of the twenty-four Superfund sites is not known at this time. However, for some of these sites soil remediation was completed (e.g., King of Prussia, NJ site). Other sites are in various phases of design or contract. Appendix B presents overview of the various soil washing demonstration and remediation projects that are completed. This information includes the site name, contractor's name, lead regulatory agency, major contaminants, and brief information on site cleanup goals, etc.

In addition U.S.EPA evaluated various soil washing technologies under the Superfund Innovative Technology Evaluation (SITE) program. Som of these projects were:

- Biotrol soil washing system for treatment of a wood preserving site

- Biogenesis soil washing technology

- Bescorp soil washing system for lead battery site treatment

- Toronto Harbour Commissioners, Soil Recycle Treatment

A list of the major soil washing contractors in the United States is presented in Appendix C. The complete list of the contractor/vendor's names may be obtained from the EPA, VISITT database. A disk copy of VISITT (version 3) may be obtained from Ahmet Suer at (803) 644-6900. 
This page intentionally left blank. 


\section{WSRC Soil Remediation Task Team}

In August $1991 \mathrm{Jim}$ Pope, ER program manager, was requested to demonstrate soil remediation technologies at SRS. The objective was to provide site-specific data for SRS remedial actions. On October 21, 1991, ERD established a sitewide WSRC Soil Remediation Task Team (task team), and held the first meeting. The task team members and organizations were:

$\begin{array}{ll}\text { Ahmet Suer, ER } & \text { Chairperson } \\ \text { Mike Barnes, SRTC } & \text { Co-chairperson } \\ \text { Mike Hart,, ER } & \text { Member } \\ \text { Chris VonLang, ER } & \text { Member } \\ \text { Doug Wyatt, ER } & \text { Member } \\ \text { Lee Dworjanyn, SRTC } & \text { Member } \\ \text { Joe Rassabi, ESS } & \text { Member } \\ \text { Michele Wilson, EPD } & \text { Member } \\ \text { Bett Dewitt, WM } & \text { Member } \\ \text { Kim Wolfe, WMT } & \text { Member } \\ \text { Jim Kupar, SE } & \text { Member } \\ \text { Glen Jackson, WMO } & \text { Member }\end{array}$

The task team reviewed 117 CERCLA waste units for contaminants, processing schedule, and prepared-technology, need-assessment table. Two soil remediation technologies identified as immediate need, were:

- Soil washing

- Low Temperature Thermal Desorption (LTTD)

Simultaneously, the task team initiated a site selection task. The purpose was to select a waste unit to demonstrate the soil remediation technologies. Based on site selection criteria, . the task team selected the following three waste units as candidates:

- D area oil basin

- FArea Burning Rubble Pit

- 716 A Motor Shops Oil Seepage Basin

In preparation for selecting a single demonstration waste unit and technology, each of the three candidate waste units were subject to screening.

A technology demonstration Work Plan (WP) was prepared in support of candidate waste units and technology selection. The WP contained:

- Field Sampling and Analysis Plan (SAP)

- Safety, Health, and Emergency Response Plan (SHERP)

- Overview of technologies 
On September 3, 1992, Ahmet Suer hosted a presentation to DOE-ER. The purpose of this meeting was to review the soil remediation project.

On December 10, 1992, the WP was submitted to SCDHEC and EPA Region IV. EPA's unofficial response was "not to pursue technology demonstrations unless the technology is the selected remedy for waste units". Due to ER budget cuts, the soil remediation demonstration project was unfunded. 


\section{Treatability Study Guidance}

The soil washing technology efficiency depends on site-specific conditions and contaminants. In order to evaluate soil washing systems for a site-specific waste unit, a literature search of treatability studies should be conducted. EPA Risk Reduction Engineering Laboratory (RREL) treatability database and various EPA literature provided good sources of information. Based on information gathered, further site-specific treatability studies may be recommended for the evaluation of the technology.

The treatability study will provide site-specific data needed to evaluate the soil washing technology. In addition, the data will help determine if the technology can meet the SRS cleanup goals.

Setting the goals/objectives of the treatability studies is critical to the ultimate usefulness of the data generated. The treatability study goals/objectives must be defined prior to initiating treatability studies.

The objectives of the treatability studies are to:

- Determine the ability of technology to remove contaminants under different operating conditions, and with various types and concentration of contaminants.

- Gather information necessary to estimate costs (operating and construction), including performance, chemical requirements, power, etc.

- Obtain information on the presence and types of by-products produced.

- Obtain information on operational issues, removal efficiency, etc.

- Aid in selection of remedy.

- Aid in the implementation of the selected remedy.

The treatability studies conducted during the remedial investigation/feasibility study (RIFS) phase of a CERCLA action determine whether soil washing technology can be used to meet the SRS cleanup goals. Conducting the treatability studies early in the RI/FS process will eliminate uncertainties associated with selecting the remedy; however, it cannot guarantee the success. The treatability studies conducted during the remedial-design/remedial-action (RD/RA) phase help establish the design and operating parameters to optimize the soil washing technology performance. 
During the treatability studies, the following parameters should be identified:*

\begin{tabular}{c} 
Parameter \\
\hline Key Physical $^{* *}$ \\
Particle size distribution: \\
$>2 \mathrm{~mm}$ \\
$0.25-2 \mathrm{~mm}$ \\
$0.063-0.25 \mathrm{~mm}$ \\
$<0.063 \mathrm{~mm}$
\end{tabular}

Purpose and Comment

\section{Other Physical}

Type, physical form, handling properties

Moisture content

Key Chemical $^{* *}$

Organics

Volatility

Partition coefficient

Metals

Humic acid

\section{Other Chemical}

pH, buffering capacity

May affect pretreatment requirements, compatibility with equipment materials of construction, wash fluid compatibility.
Oversize pretreatment requirements

Effective soil washing

Limited soil washing

Clay and silt fraction-difficult soil washing

Affects pretreatment and transfer requirements ,

Affects pretreatment and transfer requirements

Determine contaminants and assess separation and washing efficiency, hydrophobic interaction, washing fiuid compatibility, changes in washing fluid with changes in contaminants. May require preblending for consistent feed. Use the jar test protocol to determine contaminant partitioning.

Concentration and species of constituents (specific jar test) will determine washing fuid compatibility, mobility of metals, posttreatment.

Organic content will affect adsorption characteristics of contaminants on soil. Important in marinel . wetland sites. 
CERCLA guidance divides treatability studies into three tiers, each with its own goals. Planning and design of treatability studies should reflect test objectives to achieve study goals. The treatability study tiers and their primary goals are:

Laboratory screening-Determine the potential of soil washing technology to meet SRS cleanup goals and identify parameters for investigating bench and pilot scale testing. These studies are generally relatively inexpensive and short duration.

Cost range: $\quad \$ 20,000$ to $\$ 50,000$

QA/QC level: . Low level of QA/QC

Time:

One week test time, project duration is 2 months

Bench-scale testing-Verify that soil washing technology can meet cleanup goals and support remedial evaluation. Bench-scale testing can also provide cost and design information. The cost, duration, and the level of $\mathrm{QA} / \mathrm{QC}$ are generally moderate for these studies.

Cost range: $\$ 70,000$ to $\$ 100,000$

QA/QC level: Moderate to high level of QA/QC

Time: Two weeks test time, project duration 3 to 4 months

Pilot scale testing-Provide quantitative performance, cost, and design information. These tests are generally expensive and time consuming with high levels of $Q A / Q C$.

Cost range: $\quad \$ 750,000$ to $\$ 1,500,000$.

QA/QC level: $\quad$ Moderate to high level of QA/QC

Time: $\quad$ Three weeks test time, project duration 6 to 9 months

The soil washing treatability study Work Plan (WP) outlines the elements to be included in treatability testing. The WP serves as a communication device between the project management and the treatability study subcontractor. The WP consists of 10 to 15 pages and is highly recommended.

The suggested organization of the treatability study work plan is as follows:

- Project description

- Technology description

- Test objectives

- Regulatory requirements

- Test procedures

- Sampling and analysis

- Data management

- Health and Safety

- Residual management

- Attachments: (1) Organization (2) Budget 
WSRC-TR-95-0183

\section{Soil Washing Cost}

Remediation cost will depend on contaminants, soil type, cleanup goals, and secondary treatment or disposal. According to the vendors/contractors, the soil washing cost at the SUPERFUND site is shown below. These figures should be used for remediation cost estimating.

Volume (Tons)

$\$$ TTon

Up to 4,000

200 to 250

4,000 to 50,000

150

50,000 and up

100 to 125

$\left(1 \mathrm{yd}^{3}=1.5\right.$ ton of soil) 
This page intentionally left blank. 


\section{Conclusions}

, ER Engineering evaluated the soil washing technology for its potential application at the SRS waste units. Our conclusions are:

1. Soil washing can effectively remove metals, radionuclides, and organics.

2. Soil washing, in combination with other treatment technologies, may treat a wide range of contaminants.

3. Soil washing is a cost effective treatment for soils: The treatment is focused only on the appropriate fraction, instead of treating all the materials.

4. It is a relatively inexpensive treatment, compared with other ex situ soil treatment technologies.

5. No air discharge or wastewater permit is required.

6. It is an innovative treatment system; the first application at SUPERFUND site completed.

7. The clean soil has beach-sand quality, which holds about $10 \%$ moisture, and will be returned to the site.

8. It is mobile and on-site treatment.

Please feel free to call me (Ahmet Suer) if you have any questions. I can be reached at (803) 644-6900. 
This page intentionally left blank. 


\section{Bibliography}

1. U.S.EPA Soil Washing Treatment, Engineering Bulletin, December 14, 1994

2. U.S.EPA Soil Washing Treatment Engineering Bulletin, September $\mathbf{1 9 9 0}$

3. U.S.EPA Soil Washing Treatability Study

4. Vendor Publications/Literature

5. U.S.EPA ROD Abstracts

6. U.S.EPA Technology Demo Summary, March 1994 
This page intentionally left blank. 


\section{Appendix A Superfund Sites Using Soil Washing as Selected Remedy}


This page intentionally left blank. 
1. Koppers Co

Texarkana, Texas

9/8/93

2. Sandy Creek Inc. Commerce City, Colorado

3. Alaskan Battery Ent. Fairbanks, Alaska

4. Fort Lewis Logistics Center Fort Lewis, WA

5. Tinkham's Garage Londonberry, $\mathrm{NH}$

6. Bog Creek Farm Howell, NJ

7. Ewan Property Shamong Twp, NJ

8. Myers Property Franklin Twp, NJ

9. King of Prussia Winslow Twp, NJ

10. Sarney Farm Amenia, NY

11. Ordnance Works Disposal Morgantown, WV

12. Cape Fear Wood Preserving Fayetteville, NC

13. Coleman Evans Wood Preserve Jacksonville, FL

14. Cabot/Koppers Gainsville, FL

9/30/86

$9 / 30 / 85$

2

$9 / 29 / 89$

2

.

$9 / 28 / 90$

2

$9 / 28 / 90$

2

$9 / 27 / 90$

3

$9 / 29 / 89$

4

$6 / 30 / 89$

15. Moss-American Kerr-McGee Oil Milwaukee, WI

16. Wayne Waste Oil Columbia City, IN

17. Zanesville Well Field Zanesville, $\mathrm{OH}$

18. MacGillis \& Gibbs Co. New Brighton, MN

19. Koppers Co. Inc. Texarkana, TX

9/26/90

20. Lee Chemical

21. Sand Creek Industrial

22. Koppers Co. Inc. Oraville, $\mathrm{CA}$

23. FMC Corp.

24. Tinkams Garage Londonberry, NH 
This page intentionally left blank. 


\section{Appendix B Overview of Soil Washing Technology Applications in the U.S.}

Note: Soil washing technology application data for the attached projects are based on vendor literature only. Author does not certify nor confirm the accuracy of the data or vendor's claim. These soil washing application projects are for information only; further data may be obtained from lead agency or vendor. The soil washing projects are selected randomly, with contaminants similar to SRS waste units.

The author does not endorse, approve, or recommend, any of the processes or vendors.

1. King of Prussia (KOP), Superfund Site, New Jersey

2. Hanford Soil Washing Demonstration, DOE/Westinghouse Hanford Company

3. Prudhoe Bay, Alaska

4. Bruni, Texas

5. Nevada Test Site, Nevada

6. Saginaw, Michigan

7. Twin Cities Army Ammunition Plant (TCAAP), Minnesota

8. China Lake; Nevada

9. Johnson/Atoll Island, South Pacific

10. Thunder Bay, Ontario

11. Pensacola, Florida 
This page intentionally left blank. 
1. King of Prussia (KOP), Superfund Site, New Jersey

Contractor:

Lead agency:

Contaminants:
ART Remediation

U.S.EPA Region II

Heavy metals, Chromium, Copper, Nickel

On August 10, 1993, I observed a full-scale soil washing remediation at King of Prussia (KOP), a SUPERFUND site. Below is a brief description of the site and other pertaining information.

The KOP site is a 10 acres site located in the State of New Jersey. This site is adjacent to the New Jersey State Wildilife Refuge and is 1000 feet away from the Great Egg Harbor River. Operations at this site began in early 1970 s and included processing and disposing of various wastes, mainly spent acids. Six lagoons were used to process the industrial wastes. Site operations was ceased in 1975. In December 1985, the site was placed on EPA's NPL list. EPA issued a Record of Decision (ROD) for the site on September 28,1990. The ROD stated the following:

- Excavation of lagoons, extraction of metals from soils by soil washing process, and replacement of soil to original location

- Excavation of buried drums and offsite disposal

- Groundwater treatment by pump and treat (P\&T)

- Additional sampling and analysis at Great Egg Harbor River and determine further remediation at the river system.

In 1990 and 1991, EPA conducted immediate removal actions at the site. In April 1991, EPA issued an Administrative Order ( $A O)$ to the Potential Responsible Parties (PRP). This AO required PRPs to implement the ROD. The remedial design work plan was approved by EPA in December 1991.

Contaminant of concerns, contaminant concentrations, and risk based, site specific cleanup levels mandated by ROD were:

\begin{tabular}{lccc} 
Contaminant & $\begin{array}{c}\text { Concentration } \\
\text { (ppm) }\end{array}$ & $\begin{array}{c}\text { Cleanúp Levels } \\
\text { (ppm) }\end{array}$ & $\begin{array}{c}\text { Clean Soil } \\
\text { (ppm) }\end{array}$ \\
\hline Chromium & 3,000 to 5,500 & 483 & 73 \\
Copper & 10,000 & 3,500 & 110 \\
Nickel. & 6,000 & 1,935 & 25.
\end{tabular}

Treatability studies were initiated in 1992, prior to full-scale remediation and soil washing unit design. Then, about 200 tons of contaminated soils and sludges were shipped to the Heidemij plant in Netherlands. The permitting process involved US-EPA headquarters, USState Department, etc. At the Netherlands site, a one day run was performed, simulating the operations with KOP soils and sludges. The results of this test were used for site specific system design.

In May 1993, based on the full-scale test success, a full scale unit was constructed at the KOP site. Full-scale soil washing operations began on June 28, 1993. The soil washing plant capacity was 20 tons per hour (tph) and required about 1.5 acres of operating space. The soil washing plant was 34 feet high and was-located on $50-x 80-f t$ concrete pad. This 
unit consists of 12 modules. The plant's primary utility requirements are water and electric. Water consumption is about 25 gallons per minute (gpm), and water is recycled completely within the system.

The soil washing plant consists of four major subsystems:

- Screening

- Separation

- Froth flotation

- Sludge management

About 19,200 tons of soils and sludges will be processed at this site 
2. Hanford Soil Washing Demonstration, DOE/Westinghouse Hanford Company

Contractor:

ART Inc.

Lead agency:

U.S. DOE \& Hanford Westinghouse Company

Conlaminants:

Uranium, Metals, Organics

Two soil washing pilot test were conducted at the Hanford complex, to demonstrate the capability and effectiveness of soil washing.

1. The demonstration tests for the 300 tons of soil containing metals, organic materials, and low level uranium were conducted in three phase:

Phase I. Optimization phase. 50 tons of soil processed during the optimization test.

Phase II. Verification phase. 125 tons of soil were processed.

Phase III. Replication phase. 125 tons of soil processed and tests were replicated.

The mobile soil washing unit was decontaminated and released as clean.

Test results revealed that $93 \%$ reduction by weight was achieved.

2. The demonstration test for the 80 tons of soil containing elevated levels of copper and uranium was conducted. Test results revealed that $91 \%$ reduction by weight was achieved.

The ART mobile soil washing unit capacity was 10 to 15 tons/hr. 


\section{This page intentionally left blank.}


3. Prudhoe Bay, Alaska

Contractor:

Lead agency:

Contaminants:

Project cost:
Tuboscope Vetco International Environmental Services U.S. Army Corp of Engineers (ACE), Gustavus, Alaska $\mathrm{TPH}$, lead

$\$ 7,500,000$

ACE selected soil washing as a remedy for about 10,000 tons of petroleum contaminated soil. The project was completed by using countercurrent augers. The soil washing system capacity was 30 tons/hr.

Contaminants and cleanup levels were:

\begin{tabular}{lccc} 
& $\begin{array}{c}\text { TPH } \\
\text { ppm }\end{array}$ & $\begin{array}{c}\text { Total Lead } \\
\text { ppm }\end{array}$ & $\begin{array}{c}\text { TCLPLead } \\
\text { ppm }\end{array}$ \\
\hline Contaminants & 5530 & 3330 & 37 \\
Alaska Cleanup Critcria & 500 & 1000 & 5 \\
After soil washing & 207 & 224 & 2
\end{tabular}

The process consisted of an auger, which removed the gravel with high pressure hot water solution, and acetic acid was added to the water to enhance lead solubility. Finer particles then washed in flotation cells, using surfactants.

The entire treatment system was closed-loop system. A total of $4760 \mathrm{yd}^{3}$ of soil was processed and used as backfill at the site.

The remaining $240 \mathrm{yd}^{3}$ (4\%) fine grain of soil was stabilized by using Portland cement, and disposed as nonhazardous waste. Four 55-gallon drums of waste, generated as secondary waste, was stored at a RCRA landfill. 
This page intentionally left blank. 


\section{Bruni, Texas}
Contractor:
SEG
Lead agency:
State of Texas
Contaminants:
Uranium, Radium

On June 24, 1992, I observed the SEG (Westinghouse) soil washing remediation project at Bruni, Texas. Bruni site is under cognizance of Westinghouse Fuel Cycle Materials and Services (FCM\&S) and is leased from a landowner. During the mining operation, from 1975 to 1981 , uranium was produced at the site through 1000 , six-inch production wells. The contamination source was well-boring and process solution spills throughout the twenty-one acre site. Uranium contamination is located in well-boring ore, plant roots, and solution residual. Bruni site soil consisted of up to $40 \%$ clay.

At the Bruni site contaminant and cleanup levels were:

\begin{tabular}{lcc} 
Contaminant & Contaminant Ievel & Clean-up level \\
\hline Uranium & $70 \mathrm{ppm}$ & $<42 \mathrm{ppm}$ \\
Radium & $6 \mathrm{pCi} / \mathrm{g}$ & $<5 \mathrm{pCi} / \mathrm{g}$
\end{tabular}

State of Texas also requires surface soil to be fertile for growing buffe grass.

First, excavated soil is dumped in a hopper then to a classifier (screw washer). The soil is processed in a counter current spiral drum to remove soils larger than 0.625 in-diameter. The classifier has mixing paddles in the drum that wash the surfaces of these large particles with leach solution and rinse the leachate. Ammonium bicarbonate is used as a leachate agent, and it is produced on-site from ammonia $\left(\mathrm{NH}_{3}\right)$ plus carbon dioxide $\left(\mathrm{CO}_{2}\right)$ gas. The remaining contaminated soil is processed in the attrition scrubber. In the attrition scrubber particle surfaces are abraded to ensure the removal of smaller particles and the exposure of these fines to the leachate. The washed soil is sent to the mineral jig (counter current flow process). Leachates are treated for uranium and radium removal, and treated leachate is recycled for reuse. Uranium and radium are removed in ion exchange, resin column, and zeolite columns.

Soil washing operations processed 22,513 tons of contaminated soil, with a 20-ton/hr unit. 99\% of the processed soil was returned to the site as backfill, and was.capable of growing grass. $787 \mathrm{yd}^{3}$ of contaminated waste, fine roots, ion exchange resins, and zeolite were shipped off site for disposal. 
This page intentionally left blank.

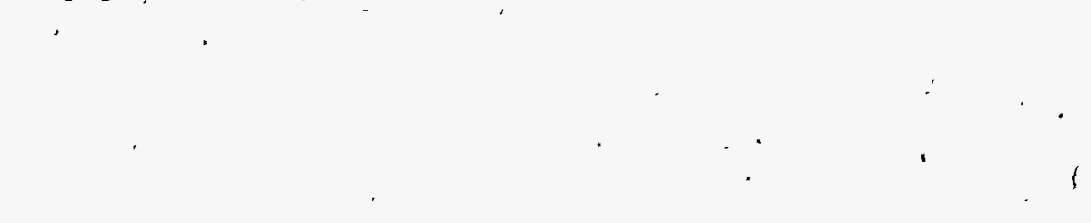

$+$ 
5. Nevada Test Site, Nevada

$\begin{array}{ll}\text { Contractor: } & \text { SEG } \\ \text { Lead agency: } & \text { U.S. Department of Energy } \\ \text { Contaminants: } & \text { Plutonium }\end{array}$

In 1994, SEG awarded a contract to perform a soil washing demonstration at the Nevada Test Site (NTS). The objective of the test was to demonstrate soil washing technology effectiveness to remove very fine particulate contaminants from the sandy clay soil.

The SEG mobile soil washing unit capacity was $1 / 4$ to 4 tons per hour, and was installed by three crews in three days. The decontamination process also took three days, and equipment was released as clean by DOE contractor.

Initial test results indicate that $80 \%$ to $99 \%$ of the soil was cleaned and returned to the site as backfill. 
This page intentionally left blank.

I 
6. Saginaw, Michigan

\section{Contractor: Bergmann USA}

Lead agency: . U.S. Army Corps of Engineers

Contaminants: $\quad$ PCBs

Bergmann USA was contracted by ACE to demonstrate a pilot-scale sail washing project. The low 5 to 10 tons per hour plant was placed on a COE dredge barge, off shore.

Prior to winter 1991, the plant processed 200 tons of PCB contaminated sediments, and an additional 300 tons of PCB contaminated soil was processed during the summer of 1992.

Test results indicated that a $91 \%$ reduction in PCB concentration was achieved, with $0.2 \mathrm{mg}$ $1 \mathrm{~kg}$ of PCBs remaining in the clean coarse sediments, with sizes of over 74 micron. The fines, less than 74 micron size, were enriched with PCBs to $14 \mathrm{mg} 1 \mathrm{~kg}$ and were scheduled for further treatment by biodegredation. 
This page intentionally left blank. 
7. Twin Cities Army Ammunition Plant (TCAAP), Minnesota

$\begin{array}{ll}\text { Contractor: } & \text { Cognis Inc. } \\ \text { Lead agency: } & \text { U.S. Army } \\ \text { Contaminants: } & \text { Lead, Chromium, Mercury, Nickel, Silver, Copper, Antimony, } \\ & \text { Cadmium }\end{array}$

The U.S. Army used the site from the 1940's to the 1960's to burn munitions and powder. Ashes were buried at the site. Heavy metals contamination was found in the upper $2 \mathrm{ft}$ of soil, over the three-acre burning site. Lead contamination averaged $6000 \mathrm{ppm}$, with a maximum of $86,000 \mathrm{ppm}$. The other heavy metals were also detected at elevated levels. Cleanup goals were set in the RCRA permit and the FFA. Lead cleanup levels were less than 175 ppm or $300 \mathrm{ppm}$ enforceable level, and the other seven heavy metals cleanup levels were "background levels."

In 1992, Cognis performed a bench-scale treatability study, and Cognis used the TERRAMET leaching process with the Bescorp Inc. soil washing process at this site. Recovered lead was sent for recycling. The Cognis system capacity.was 10 to 20 tons per hour, and a total of 11,600 tons of soil was processed. 
This page intentionally left blank. 


\section{China Lake, Nevada}

$\begin{array}{ll}\text { Contractor: } & \text { AWC (a Lockheed Company) } \\ \text { Lead agency: } & \text { U.S. Department of Defense; Navy } \\ \text { Contaminants: } & \text { Depleted Uranium }\end{array}$

At the Naval Weapons Center (NWC), test firing of $120-\mathrm{mm}$ depleted uranium (DU) penetrators continued for 10 years. The DU penetrators were fired into the catch box from distances of 3 kilometers. The catch box was $20 \mathrm{ft}$ by $20 \mathrm{ft}$ and $30 \mathrm{ft}$ deep. A steel barrier was placed in front of the catch box. In the ten-year period 25,000 pounds of DU was fired at the test site.

Initial contamination lcvels were $134 \mathrm{pCi} / \mathrm{gm}$ of $\mathrm{DU}$ activity. In 1991, during the demonstration, 39 tests were run. Test results indicated that $95 \%$ volume reduction was achieved. The AWC mobile soil washing unit includes the TRUClean process, which consist of:

- Particle size fractionation

- Gravimetric separalion

- Chemical extraction

The AWC mobile unit consist of 11 modules mounted on 9 trailer trucks. Details of the process are proprietary information. The AWC mobile soil washing unit capacity at this site was $10 \mathrm{yd}^{3} \mathrm{hr}$. 
This page intentionally left blank.

, 


\section{Johnson/Atoll Island, South Pacific}

$\begin{array}{ll}\text { Contractor: } & \text { AWC (a Lockheed Company) } \\ \text { Lead agency: } & \text { U.S. Defense Nuclear Agency } \\ \text { Contaminants: } & \text { Plutonium }\end{array}$

This was the first soil washing project completed by a U.S. firm. In 1985, the TRUClean/soil washing system was tested by the Defense Nuclear Agency at the Johnson/Atoll Island in the South Pacific. Plutonium-239-contaminated native coral soil was processed, and 95\% volume reduction achieved.

In 1988, AWC installed a $15 \mathrm{yd}^{3}$ mobile unit at the Johnson Atoll Island, and processed $1400 \mathrm{yd}^{3}$ of soil. 
This page intentionally left blank. 
10. Thunder Bay, Great Lakes, Ontario

Contractor: Biogenesis

Lead agency: International Joint Commission of U.S. and Canada

Contaminants: PAH, PCBs, phenol, heavy metals

The Biogenesis soil washing process is an ex-situ extraction process that washes soil with proprietary bioremediating surfactants and water.

At this former wood preserving site, $80 \%$ of the sediments had 38-micron particle size, or less. About $20,000 \mathrm{~m}^{3}$ of soil was treated. During the three wash cycles $90 \%$ removal of PAfIs was achieved.

The tests results were:

\begin{tabular}{lccc}
\multicolumn{1}{c}{ Contaminants } & $\begin{array}{c}\text { Before } \\
\text { Washing (ppm) }\end{array}$ & $\begin{array}{c}\text { After } \\
\text { Washing (ppmi) }\end{array}$ & $\begin{array}{c}\text { Percent } \\
\text { Removal (ppm) }\end{array}$ \\
\hline TPH & 4,770 & 400 & $91.6 \%$ \\
Oil and grease & 91.600 & 3,940 & $95.7 \%$ \\
Semivolatile petr. IIC & 21.000 & 2,200 & $89.5 \%$ \\
Naphthalene & $1,400,000 \mathrm{ppb}$ & $73,000 \mathrm{ppb}$ & $94.8 \%$ \\
Benzoanthracene & $115,000 \mathrm{ppb}$ & $19.000 \mathrm{ppi}$ & $83.5 \%$
\end{tabular}

$-$ 


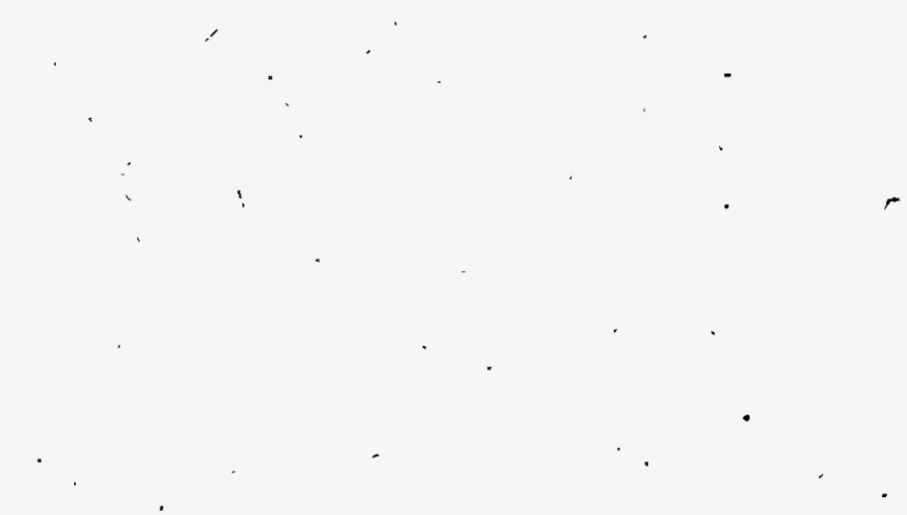

This page intentionally left blank. 
11. Pensacola, Florida

Vendor:

Lead agency:

Contaminants:

\section{U.S.EPA RREL}

U.S.EPA

Pentachlorophenol (PCP), creosote-PAHs

In November 1992, the demonstration of EPA's mobile soil washing unit was performed under the SITE program at the Escambia Wood Treating Company site located in Pensacola, FL. The demonstration test period was 2 weeks. During the demonstration EPA mobile soil washing unit operated at $100 \mathrm{lb} / \mathrm{hr}$ with washwater-to-feed ratio of 6 to 1 . The 26-acre Escambia site used PCP and creosote to treat wood products from 1943 to 1982.

The EPA's mobile soil washing unit was designed to remove contaminants by soil washing and volume reduction of contaminated soil by particle size separation.

The demonstration test results indicated that the tests were successful, and separated the contaminants into washed soil, and fines slurry. The fines slurry retreated to separate fines from water.

Economic analysis indicate that the cost to remediate 20,000 tons of contaminated soil, using the same process, with a 10 tph-unit, is estimated to be $\$ 130$ per ton. 
This page intentionally left blank. 
Appendix C Soil Washing Contractor/Vendor List 
This page intentionally left blank.

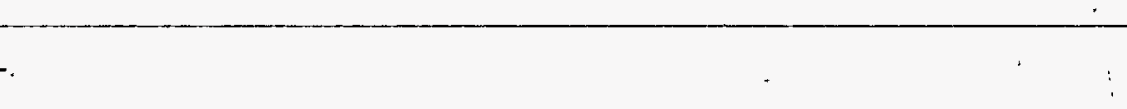


Some of the soil washing contractors/vendors are:

1. ART, Inc.

2. AWC/Lockhead

3. Biogenesis

4. Bergmann USA

5. Canonie Environmental Services

6. Cognis

7. Ecova

8. Genesis Eco System

9. Interra

10. OHM

11. SEG

12. Tuboscope Vitco International

13. Waste Management/Rust

14. Westinghouse Remediation Services 
This page intentionally left blank. 